\title{
PENINGKATAN AKTIVITAS BELAJAR MATEMATIKA MELALUI PENDEKTAN PROBLEM BASED LEARNING BAGI SISWA KELAS 4 SD
}

\author{
Normala Rahmadani N., Indri Anugraheni \\ 292013162@Student.uksw.edu, indri.anugraheni@staff.uksw.edu \\ PGSD, Universitas Kristen Satya Wacana
}

\begin{abstract}
IMPROVING MATH LEARNING ACTIVITIES THROUGH PROBLEM BASED LEARNING APPROACH FOR 4TH GRADE STUDENTS
\end{abstract}

\begin{abstract}
The purpose of this study is to determine whether the increase in learning activities mathematics can be pursued through the approach of PBL grade 4 students SDN Petirrejo in the 2nd semester of 2017. The data collection techniques was with observation, and the research instruments were in the form of observation sheet of learning activities. The data analysis was done by comparative descriptive statistical technique to compare the number of students who have high learning activity of Mathematics between cycle I and cycle II. The results showed that the increase in learning activity can be done through the approach of PBL grade 4 students, proved from the increase from cycle I to cycle II. The visual activity in cycle I resulted 95,8\%, and in cycle II 100\%; this showed an increase of 4,2\% between the cycles. The oral activity in cycle I resulted 37,5\%, and in cycle II 79,16\%; the increase equals to $41,6 \%$. The listening activity in cycle I resulted 62,5\%, and in cycle II 70,83\%; the increase equals to $8,33 \%$. The writing activity in cycle I was $79.1 \%$, and in cycle II was 83.33\%; which showed an increase of $12.5 \%$. The mental activity in cycle I was 62.5 , and in cycle II $70.83 \%$, which increased by $8.33 \%$.
\end{abstract}

Keywords: Learning activities, Problem-based Learning

Received date: 28 April $2017 \quad$ Revised date: 3 Mei 2017

Accepted date: 18 September 2017

\section{PENDAHULUAN}

Pendidikan merupakan usaha yang dilakukan manusia secara terus menerus (sepanjang hayat) dalam kehidupannya. Pendidikan juga dapat disebut sebagai proses memanusiakan manusia, dimana melalui pendidikan seseorang dapat mempertahankan eksistensinya dalam kehidupan sehari-hari. Dalam Undang-undang Sisdiknas No. 20 tahun 2003 Bab I pasal 1 (1) yang berbunyi "yang dimaksud dengan pendidikan adalah usaha sadar dan terencana mewujudkan suasana belajar dan proses pembelajaran agar siswa secara aktif mengembangkan potensinya sendiri". Hal tersebut menunjukkan bahwa dalam mewujudkan suatu pendidikan yang sesuai dengan undang-undang sisdiknas serta pendidikan yang mampu mengembangkan potensi siswa adalah pendidikan yang didalamnya terdapat pembelajaran yang menuntut setiap subyek pembelajranya (siswa) untuk aktif agar mampu mengembangkan setiap potensinya serta kecerdasan dan kepribadiannya seperti yang tertera pada tujuan dari pendidikan nasional.

Pembelajaran serupa terjadi pada kelas 4 SDN Petirrejo Kecamatan Ngadirejo Kabupaten Temanggung, guru menjadi subyek pembelajaran, aktivitas belajar siswa kelas 4 SDN Petirrejo Kecamatan Ngadirejo Kabupaten Temanggung sangat terbatas. Terutama pada mata pelajaran Matematika. Dalam proses belajar mengajar siswa kurang aktif. Misalnya, masih kurang beraninya siswa untuk bertanya, mengungkapkan pendapatnya, serta aktivitas di dalam kelas hanya menyimak buku, mengerjakan soal di depan kelas, mengerjakan soal latihan yang diberikan oleh guru, dan diskusi kelompok. Dalam menyampaikan materi pembelajaran guru menggunakan metode ceramah 
Peningkatan Aktivitas Belajar Matematika Melalui Pendektan Problem Based Learning Bagi Siswa Kelas 4 SD (Normala Rahmadani N., Indri Anugraheni)

dan diskusi. Aktivitas siswa dalam pembelajaran terbatas pada aktivitas mendengarkan guru dan diskusi, tidak ada aktivitas lain yang mendukung proses pembelajaran. Pengelolaan pembelajaran yang demikian akan menyebabkan aktivitas belajar siswa tidak optimal.

Salah satu cara untuk meningkatkan aktivitas belajar siswa adalah dengan menerapkan pendekatan pembelajaran yang dapat memacu siswa untuk beraktivitas didalamnya. Pendekatan pembelajaran yang dapat meningkatkan aktivitas belajar siswa adalah pendekatan Problem Besed Learning (PBL). Boud dan Feletti dalam Riyanto (2010:285) mendefinisikan pendekatan PBL sebagai suatu pendekatan ke arah penataan pembelajaran yang melibatkan siswa untuk menghadapi permasalahan melalui praktik nyata dalam kehidupan sehari-hari. Pendekatan PBL menekankan pada aktivitas pemecahan masalah dalam pembelajaran. Melalui pendekatan PBL siswa belajar melalui aktivitas pemecahan masalah yang dapat mengasah keterampilan berpikir siswa.

Berdasarkan permasalahan tersebut maka permasalahan pokok dalam penelitian ini adalah kurangnya aktivitas belajar siswa dalam mata pelajaran Matematika. Hal yang dapat dilakukan untuk mengatasi masalah tersebut yaitu dengan menggunakan pendekatan PBL.

\section{KAJIAN PUSTAKA \\ Aktivitas Belajar}

Kegiatan pembelajaran siswa melakukan aktivitasnya sendiri, guru bertugas menjadi fasilitator. Hal tersebut dikemukakan oleh Sardiman (2014:99) bahwa pendidik tugasnya menyediakan makanan dan minuman rohani anak, akan tetapi yang memakan serta meminumnya adalah anak didik itu sendiri. Thomas M. Risk dalam Rohani (2010:6) mengemukakan tentang belajar mengajar sebagai berikut: "Teaching is guidance of learning experiences" (mengajar adalah proses membimbing pengalaman belajar). Pengalaman itu sendiri hanya mungkin diperoleh jika siswa itu dengan keaktifannya sendiri bereaksi dengan lingkungannya.Sardiman (2014:100) menjelaskan bahwa yang dimaksud aktivitas belajar adalah aktivitas yang bersifat jasmani maupun psikis. Aktivitas ini berarti dua perbuatan yang terkait. Perbuatan ini dapat menghasilkan belajar yang optimal apabila antara perbuatan jasmani seperti siswa yang sedang membaca dan perbuatan psikis seperti siswa berpikir tentang sesuatu, itu seimbang dan sebaliknya. Perbuatan seimbang itulah yang dinamakan aktivitas belajar. Rohani (2010:6) mendefinisikan aktivitas itu sebagai giat yang dilakukan oleh siswa baik jasmani maupun giat dalam melibatkan psikis. Jean piaget dalam Rohani (2010:8-9) menjelaskan bahwa aktivitas atau kegiatan adalah apabila siswa melakukan sesuatu ke arah perkembangan jasmani dan kejiwaan. Mendasarkan pada tiga pandangan pakar tentang aktivitas belajar, aktivitas belajar adalah seluruh aktivitas siswa dalam proses belajar, mulai dari kegiatan fisik sampai kegiatan psikis. Kegiatan fisik berupa ketrampilan-ketrampilan dasar sedangkan kegiatan psikis berupa ketrampilan terintegrasi. Ketrampilan dasar yaitu mengobservasi, mengklasifikasi, memprediksi, mengukur, menyimpulkan dan mengkomunikasikan. Sedangkan ketrampilan terintegrasi terdiri dari mengidentifikasi variabel, membuat tabulasi data, menyajikan data dalam bentuk grafik, menggambarkan hubungan antar variabel, mengumpulkan dan mengolah data, menganalisis penelitian, menyusun hipotesis, mendefinisikan variabel secara operasional, merancang penelitian dan melaksanakan eksperimen.

Usman (2011:6) menggolongkan aktivitas belajar siswa ke dalam beberapa hal sebagai berikut, aktivitas visual, aktivitas lisan,aktivitas mendengarkan, aktivitas gerak, aktivitas menulis. Menurut Paul B. Diedrich dalam Sardiman (2014:101) mengemukakan 117 kegiatan siswa yang dibagi dalam Visual activities, Oral activities, Listening activities, Writing activities, Drawing activities, Motor activities, Mental activities, Emotional activities. Menurut Dierich yang dikutip Hamalik (2014:288209) menyatakan bahwa aktivitas belajar dibagi menjadi delapan kelompok yaitu, Kegiatan-kegiatan visual, kegiatan-kegiatan lisan (oral), kegiatan-kegiatan mendegarkan,kegiatan-kegiatan menulis, kegiatan-kegiatan menggambar, kegiatan-kegiatan metrik, kegiatan-kegitan mental, kegiatan-kegiatan emosional

Mendasarkan pada pendapat yang telah dikemukakan oleh para ahli, peneliti akan menggunakan beberapa jenis-jenis aktivitas menurut Paul B. Diedrich dalam Sudirman (2014:101) yaitu: 1) Visual activities; 2) Oral activities; 3) Listening activities; 4) Writing activities; dan 5) Mental activities. 


\section{Pendekatan Problem Based Learning}

Pendekatan PBL merupakan salah satu pendekatan dalam pembelajaran yang membantu siswa untuk mengembangkan aktivitas siswa dalam pembelajaran. Margetson dalam Rusman (2013:230); Boud dan Feletti dalam Riyanto (2010:285); Boud dan Feletti, Ibrahim dan Nur dalam Rusman (2013:241); Moffit dalam Rusman (2013:241; (Rusman, 2013:241-242), mendasarkan pada pandangan para ahli tersebut pendekatan PBL adalah pendekatan pembelajaran yang menggunakan permasalahan dunia nyata sebagai suatu konteks, guna merangsang kemampuan berpikir kritis serta kemampuan pemecahan masalah siswa dalam memahami konsep dan prinsip yang esensi dari materi pelajaran.

Karakteristik pendekatan PBL menurut beberapa ahli yaitu (Rusman, 2013:232); Arends dalam Riyanto (2010:287); berdasarkan karakteristik yang dikemukakan beberapa ahli, karakteristik pendekatan PBL terdiri dari adanya permasalahan yang kongkret atau masalah yang ada di masyarakat, masalah yang ada harus dibuat semenarik mungkin agar siswa termotivasi dalam belajar, pendekatan PBL menekankan pada pembelajaran yang bersifat kolaboratif, komunikatif dan kooperatif (tim), dalam menerapkan pendekatan PBL sumber belajar tidak hanya diambil dari satu sumber belajar saja, dan pendekatan PBL mengutamakan belajar mandiri (siswa aktif), solusi yang didapat siswa dikomunikasikan di depan kelas.

. Pendekatan PBL menekankan pada pemecahan masalah dalam proses pembelajaran. Langkahlangkah pendekatan PBL yang digunakan penliti yaitu mengutip dari Hosnan (2014:301) mengemukakan tahapan dalam pendekatan PBL yaitu, orientasi siswa pada masalah. Guru menjelaskan tujuan pembelajaran, menjelaskan logistik yang diperlukan, memotivasi siswa terlibat pada aktivitas pemecahan masalah yang dipilih, mengorganisasi siswa untuk belajar. Guru membantu siswa mendefinisikan dan mengorganisasikan tugas belajar yang berhubungan dengan masalah tersebut, membimbing pengalaman individual atau kelompok. Guru mendorong siswa untuk mengumpulkan informasi yang sesuai, melaksanakan eksperimen untuk mendapatkan penjelasan dan pemecahan masalahnya, mengembangkan menyajikan hasil karya. Guru membantu siswa dalam merencanakan dan menyiapkan karya yang sesuai seperti laporan, video dan model serta membantu berbagi tugas dengan temannya, menganalisis dan mengevaluasi proses pemecahan masalah. Guru membantu siswa untuk melakukan refleksi atau evaluasi terhadap penyelidikan mereka dan proses yeng mereka gunakan.

Kelebihan dan Kelemahan pendekatan PBL.Secara umum dapat dikemukakan bahwa kelebihan dan kelemahan dari penerapan pendekatan PBL antara lain (Warsono dan Hariyanto, 2013:152), Siswa akan terbiasa menghadapi masalah (problem posing) dan merasa tertantang untuk menyelesaikan masalah, tidak hanya terkait dengan pembelajaran dalam kelas, tetapi juga menghadapi masalah yang ada dalam kehidupan sehari-hari (real world), memupuk solidaritas sosial dengan terbiasa berdiskusi dengan teman-teman sekelompok kemudian berdiskusi dengan teman-teman sekelasnya, makin mengakrabkan guru dengan siswa, karena ada kemungkinan suatu masalah harus diselesaikan siswa melalui eksperimen hal ini juga akan membiasakan siswa dalam menerapkan metode eksperimen.

Kelemahan pendekatan PBL (Warsono dan Hariyanto, 2013:152: tidak banyak guru yang mampu mengantarkan siswa kepada pemecahan masalah, seringkali memerlukan biaya yang mahal dan waktu yang panjang, aktivitas siswa yang dilaksanakan di luar sekolah sulit dipantau guru.

\section{Pembelajaran Matematika di SD}

Hakekat Matematika, matematika merupakan salah satu disiplin ilmu yang dapat meningkatkan kemampuan berfikir dan beragumentasi, memberikan kontribusi dalam menyelesaikan masalah sehari-hari dan dalam dunia kerja sehingga matematika sangatlah penting untuk kita pelajari.Dalam pembelajaran matematika di SD, diharapkan terjadi reinvention (penemuan kembali). Penemuan kembali adalah menemukan suatu cara penyelesaian secara informal dalam pembelajaran di kelas, walaupun penemuan itu sederhana dan bukan hal baru bagi orang yang telah mengetahui sebelumnya, tetapi bagi siswa SD penemuan tersebut merupakan sesuatu hal yang baru. Sumum tujuan pembelajaran matematika di sekolah dasar adalah agar siswa mampu dan terampil menggunakan matematika. Selain itu juga, dengan pembelajaran matematika dapat memberikan tekanan penataran nalar dalam penerapan matematika. Secara khusus, tujuan pembelajaran 
Peningkatan Aktivitas Belajar Matematika Melalui Pendektan Problem Based Learning Bagi Siswa Kelas 4 SD (Normala Rahmadani N., Indri Anugraheni)

matematika di sekolah dasar menurut Depdiknas dalam Ahmad Suseno (2013:190) yaitu, memahami konsep matematika, menjelaskan keterkaitan antar konsep dan mengaplikasikan konsep atau algoritma, menggunakan penalaran pada pola dan sifat, melakukan manipulasi matematika dalam generalisasi, menyusun bukti, atau menjelaskan gagasan dan pernyataan matematika, memecahkan masalah yang meliputi kemampuan memahami masalah, merancang model matematika, menyelesaikan model dan menafsirkan solusi yang diperoleh, mengomunikasikan gagasan dengan simbol, tabel, diagram, atau media lain untuk memperjelas keadaan atau masalah, dan memiliki sikap menghargai kegunaan matematika dalam kehidupan sehari-hari.

Secara garis besar ruang lingkup pokok pembahasan matematika di SDmeliputi lima poin seperti yang tercantum di dalam Permendiknas No. 22 Tahun 2006, yaitu:Unit aritmatika (berhitung)atau berhitung mendapat porsi dan penekanan utama. Sebagian besar dari kajian di SD adalah berhitung, Unit pengantar aljabaradalah perluasan terbatas dari unit matematika dasar. Dengan dasar pemahaman tentang pemahaman, dilakukan pengenalan perintisan aljabar, unit geometri mengutamakan pengenalan bangun datar dan bangun ruang, unit Pengukuran diperkenalkan sejak kelas 1 sampai kelas 6 dan diawali dengan pengukuran tanpa menggunakan satuan baku. Konsep-konsep pengukuran yang diperkenalkan mencakup pengukuran panjang, keliling, luas, berat, volume, sudut, dan waktu dengan satuan ukuranya, unit kajian data yang dimaksud kajian data adalah pembahasan materi statistik secara sederhana di SD. Dalam kajian ini terdapat kegiatan pengumpulan data, menyusun data, menyajikan data secara sederhana serta membaca data yang telah disajikan dalam bentuk diagram.

Implementasi model pembelajaran $P B L$, secara teoritik dapat meningkatkan aktivitas hasil belajar penelitian yang dilakukan oleh Deni Kartika Sari dengan mengambil judul "Penerapan Model Problem Based Learning dengan Media Power Point Untuk Meningkatkan Aktivitas Belajar IPA Siswa Kelas V SDN 2 Mudal". Hasil penelitian menunjukkan peningkatan aktivitas siswa dari jumlah skor rata-rata kelas 12,93 pada siklus I pertemuan 1 menjadi jumlah skor rata-rata kelas 17,14 siklus I pertemuan 2 menjadi jumlah skor rata-rata kelas 21,38 siklus II pertemuan 1 menjadi jumlah skor rata-rata kelas 24,93 pada siklus II pertemuan 2. Penerapan model problem based learning merupakan cara yang efektif untuk meningkatkan aktivitas belajar IPA. Berdasarkan penelitian yang dilakukan oleh Deni, nampak bahwa penelitian ini memiliki kelebihan yaitu dapat meningkatkan aktivitas belajar siswa. Namun di sisi lain penelitian ini juga memiliki kelemahan yaitu penelitian ini mengukur lebih dari dua variabel terikat, yang menyebabkan penelitian ini menjadi tidak fokus serta hasil yang dicapai tidak maksimal. Oleh karena itu untuk mengatasi hal tersebut sebaiknya penelitian dilaksanakan lebih fokus pada satu variabel terikat yaitu aktivitas belajar, sehingga dapat memaksimalkan peningkatan aktivitas belajar IPA.

Penelitian lain yang sejalan adalah penelitian yang dilakukan oleh Rizka Vitasari dengan mengambil judul "Peningkatan Keaktifan dan Hasil Belajar Matematika melalui Model Problem Based Learning Siswa Kelas V SD Negeri 5 Kutosari”. Penelitian ini menggunakan teknik penelitian tindakan kelas kolaboratif. Subyek penelitian ini adalah siswa kelas V berjumlah 16 siswa. Tujuan penelitian ini adalah (1) mendeskripsikan langkah-langkah penerapan model problem based learning, (2) meningkatkan keaktifan, dan (3) meningkatkan hasil belajar matematika. Penelitian ini menggunakan teknik penelitian tindakan kelas kolaboratif. Subyek penelitian ini adalah siswa kelas V berjumlah 16 siswa. Prosedur penelitian tindakan kelas berupa perencanaan, pelaksanaan, observasi dan refleksi. Pelaksanaan tindakan dilaksanakan dalam dua siklus masing-masing siklus tiga pertemuan. Teknik pengumpulan data yang digunakan adalah observasi, wawancara, angket, dan tes. Validitas data menggunakan teknik triangulasi sumber dan triangulasi teknik. Analisis data menggunakan teknik analisis kuantitatif dan kualitatif, meliputi reduksi data, sajian data, dan verifikasi data. Hasil penelitian menunjukkan persentase rata-rata keaktifan belajar siswa pada siklus I sebesar $61,2 \%$, dan siklus II sebesar 90,5\%, dari siklus I menuju ke siklus II mengalami peningkatan sebesar 29,3\%. Hasil tersebut menunjukkan bahwa penerapan model problem based leaning dapat meningkatkan keaktifan dan hasil belajar matematika pada siswa kelas V Sekolah Dasar.Berdasarkan hasil penelitian yang dilakukan oleh Rizka, nampak bahwa keaktifan belajar siswa telah mengalami peningkatan. Namun penelitian kurang terfokus karena mengukur lebih dari satu variabel terikat. Cara mengatasi kelemahan penelitian ini yaitu dalam pelaksanaan pembelajaran lebih difokuskan lagi untuk memperoleh hasil yang maksimal. 
Penelitian lain membahas tentang penerapan PBL untuk meningkatkan aktivitas dan hasil belajar siswa. Vivin Nurul Agustin mengadakan penelitian pada mata pelajaran matematika dengan mengambil judul " Peningkatan Aktivitas dan Hasil Belajar Siswa Menggunakan Model Pembelajaran Problem Based Learning". Hasil penelitian pada siklus I, aktivitas belajar siswa dalam pembelajaran siklus I 66,28\% (tinggi) dan meningkat pada siklus II menjadi 76,50\% (sangat tinggi). Penerapan model PBL dapat meningkatkan hasil dan aktivitas belajar siswa dalam pembelajaran matematika materi pecahan di kelas IV SD Negeri 01 Wanarejan Pemalang. Kelebihan dari penelitian ini adalah PBL mampu meningkatkan aktivitas dan hasil belajar. Selain kelebihan, penelitian ini juga memiliki kekurangan yaitu dalam penelitian tidak dijelaskan keterkaitan antara hasil dan aktivitas belajar, keduanya masih berdiri sendiri. Cara mengatasi kelemahan tersebut adalah sebaiknya dalam penelitian lebih ditonjolkan keterkaitan antara hasil dan aktivitas belajar, agar kedua variabel tersebut tidak terkesan berdiri sendiri namun keduanya saling berhubungan dan mempengaruhi.

Sri Candra Dewi melakukan penelitian yang serupa dengan judul "Penerapan Model Problem Based Learning Dengan Media Puzzle Untuk Meningkatkan Kualitas Pembelajaran IPA Di Kelas IVB SDN Tambakaji 04". Kualitas pembelajaran yang akan diukur meliputi keterampilan guru, aktivitas dan hasil belajar siswa. Hasil penelitian menunjukkan aktivitas siswa, untuk siklus I diperoleh rata-rata skor 20,13 kategori baik menjadi rata-rata skor 26,25 kategori baik pada siklus II. Berdasarkan hasil penelitian, simpulan yang diperoleh adalah model problem based learning dapat meningkatkan aktivitas belajar IPA. Penelitian ini memiliki kelebihan yaitu model PBL dapat meningkatkan aktivitas belajar IPA. Kelemahan dari penelitian ini adalah peningkatan aktivitas belajar siswa kurang signifikan, dimana aktivitas belajar siswa dari siklus I ke siklus II hanya mencapai skor peningkatan sebesar 6,12. Selain itu penelitian kurang terfokus karena mengukur lebih dari satu variabel terikat. Cara mengatasi kelemahan penelitian ini yaitu dalam pelaksanaan pembelajaran lebih difokuskan lagi, sehingga aktivitas belajar siswa mengalami peningkatan yang lebih signifikan.

\section{METODE PENELITIAN}

Penelitian ini dilaksanakan di SDN Petirrejo Ngadirejo pada kelas 4 semester 2 tahun pelajaran 2016/2017. Penelitian ini diawali dengan pembuatan proposal pada bulan Januari. Siklus pertama dilakukan pada 20-21 Maret 2017 sedangkan siklus kedua dilaksanakan pada 27-28 Maret 2017. Subyek penelitian ini siswa kelas 4 SDN Petirrejo Kecamatan Ngadirejo yang berjumlah 24 siswa yang terdiri dari 13 siswa laki-laki dan 11 siswa perempuan. Sumber data berasal dari sumber data primer. Sumber data primer diperoleh dari hasil aktivitas belajar siswa. Teknik pengumpulan data pada penelitian ini menggunakan teknik non tes. Teknik non tes digunakan untuk memperoleh data tentang aktivitas belajar siswa. Kisi-kisi instrumen aktivitas belajar terdiri dari 5 item aktivitas dan 8indikator. Analisis data digunakan untuk mengukur instrument yang valid. Valid berarti instrumen tersebut dapat digunakan untuk mengukur apa saja yang akan diukur.

Penggunan instrumen yang valid dalam pengumpulan data, diharapkan hasil penelitian akan menjadi valid. Jadi instrumen yang valid merupakan syarat untuk mendapatkan hasil penelitian yang valid (Sugiyono, 2012:348). Teknik yang digunakan untuk mengetahui kesejajaran adalah teknik korelasi product moment yang dikemukakan oleh Pearson berikut ini (Arikunto, 2012:85). Instrumen aktivitas belajar Matematika terdiri dari 5 indikator aktivitas belajar yakni, aktivitas visual, aktivitas lisan, aktivitas, mendengarkan, aktivitas menulis, dan aktivitas mental. Penilaian aktivitas belajar Matematika melalui pendekatan PBL ditentukan berdasarkan kriteria aktivitas belajar Matematika. Kriteria aktivitas belajar IPA dikelompokkan menjadi 3 yaitu, sedikit (0-2 aktivitas), sedang (3-5 aktivitas), tinggi (6-8 aktivitas).

\section{HASIL DAN PEMBAHASAN \\ Dekripsi Hasil tiap Siklus dan antar Siklus}

Pelaksanaan tindakan pada siklus I pada pembelajaran matematika dengan pendekatan pembelajaran Problem Based Learning dilaksanakan dalam 2 pertemuan dengan materi pembelajaran pengurangan bilangan bulat. Berikut ini akan dibahas tahapan pelaksanaan pembelajaran dengan model Problem Based Learning tiap pertemuan. Pertemuan pertama dilaksanakan pada tanggal 20 Maret 2017 pada jam pelajaran pertama sampai kedua, semua siswa mengikuti pembelajaran tanpa 
ada siswa yang izin tidak masuk sekolah. Pada pertemuan ini penelitian membahas materi konsep pengurangan bilangan bulat. Langkah -langkah pelaksanaan pembelajaran dengan pendekatan Problem Based Learning diuraikan sebagai berikut: Pada tahap awal guru mengucapkan salam pembuka, guru mengabsen kehadiran siswa, mengkondisikan siswa, apersepsi yaitu dengan mengulas kembali materi yang diajarkan sebelumnya, kemudian guru menyampaikan tujuan pembelajaran dan kemudian guru memberikan soal pretest kepada siswa. Pada tahap ini guru melaksanakan langkah yaitu orientasi siswa pada masalah.Pada tahap inti guru bertanya jawab dengan siswa mengenai pengurangan bilangan bulat, guru memberikan masalah yang berkaitan dengan operasi bilangan bulat yaitu dengan menunjukkan video pembelajaran yaitu pengurangan bilangan bulat, guru membentuk siswa dalam kelompok 6 kelompok yang beranggotakan 4 siswa, guru memerintahkan siswa untuk mengerjakan bersama kelompok, guru membagikan handout yang berisi kan uraian materi dan permasalahan tentang pengurangan bilangan bulat. Pada tahap ini guru melaksanakan langkah PBL yaitu Mengorganisasi siswa untuk belajar. Kemudian guru memberikan kesempatan kepada siswa untuk berfikir dan bertindak menurut kemampuan masing-masing siswa dan guru berperan sebagai fasilitator, guru berkeliling untuk mengamati, memotivasi dan memfasilitasi serta membantu siswa yang memerlukan. Pada tahap ini guru melaksanakan langkah PBL yaitu Membimbing penyelidikan individual maupun kelompok.Kemudian guru meminta setiap kelompok untuk mempresentasikan hasil kerja kelompok yang telah dikerjakan dan kelompok lainnya menanggapi atau mengkomunikasikan hasil kerja kelompok yang mendapat tugas, guru memberi penguatan terhadap jawaban siswa, yaitu dengan mengacu pada jawaban siswa dan melalui tanya jawab membahas penyelesaian masalah yang seharusnya, guru bertanya jawab membahas penyelesaian masalah yang seharusnya.Pada tahap penutup gurumembuat penegasan atau kesimpulan cara pengurangan bilangan bulat, guru bertanya kepada siswa tentang hal-hal yang belum dipahami siswa selama kegiatan pembelajaran, guru menutup pembelajaran dengan mengucap salam penutup. Pada tahap ini guru melaksanakan langkah PBL yaitu Menganalisis dan mengevaluasi proses pemecahan masalah.

Pertemuan keduatahap awal dilaksanakan pada tanggal 21 Maret 2017 pertama guru mengkondisikan siswa, guru mengucapkan salam, guru mengajak berdo'a sebelum pembelajaran dimulai kemudian guru mengecek kehadiran siswa, apersepsi dengan mengulang materi sebelumnya, dan menyampaikan tujuan pembelajaran.Pada tahap inti pertemuan kedua ini guru membahas hasil kerja kelompok yang telah dikerjakan pada pertemuan pembelajaran sebelumnya, guru memberi kesempatan kepada setiap siswa untuk bertanya hal-hal tentang materi yang telah dipelajari yang mungkin masih sulit dimengerti oleh siswa, kemudian guru memberikan kesempatan kepada siswa lain untuk memberi tanggapan atau sanggahan terhadap pertanyaan yang mungkin muncul saat pembelajaran.Pada tahap akhir pertemuan kedua ini guru meluruskan kesalah pahaman yang mungkin dialami siswa saat mengikuti kegiatan pembelajaran, kemudian guru menutup kegiatan pembelajaran dengan berdo'a dan mengucapkan salam.

Pada bagian refleksi seluruh rangkaian kegiatan pembelajaran dilaksanakan di siklus I pertemuan ke 1 dan pertemuan ke 2 kegiatan yang dilakukan selanjutnya adalah refleksi tentang seluruh kegiatan yang dilakukan pada kegiatan belajar mengajar. Kegiatan refleksi mengacu pada seluruh kegiatan yang telah dilaksanakan sesuai dengan pembelajaran berlangsung diantaranya ialah aktivitas belajar siswa, hasil observasi kegiatan mengajar guru, dan hasil observasi kegiatan belajar yang dilaksanakan pada siklus I pertemuan ke 1 dan pertemuan ke 2 tentang pengurangan bilangan bulat. Kegiatan ini dilaksanakan untuk bahan perbaikan dengan membandingkan proses pembelajaran yang dilakukan sudah sesuai dengan indikator yang ingin dicapai dalam penelitian. Refleksi pada siklus I adalah hasil observasi kegiatan mengajar guru yang dilaksanakan pada siklus I pertemuan ke 1 masih terdapat beberapa kekurangan dan belum sesuai dengan indikator keberhasilan yang ingin dicapai peneliti, antara lain adalah guru tidak menyampaikan tujuan pembelajaran yang akan dilaksanakan, tidak adanya pemberian motivasi kepada siswa, dan guru belum meluruskan kesalah pahaman yang terjadi dan belum memberikan tindak lanjut berupa pekerjaan rumah tentang materi yang diajarkan. Guru juga perlu meningkatkan keaktifan siswa dalam mengerjakan tugas dan kegiatan bekerja secara kelompok.Berdasarkan hasil observasi kegiatan belajar mengajar siswa di siklus I pertemuan ke 1 bahwa ada beberapa yang belum dilakukan oleh siswa antara lain adalah siswa belum mendapatkan penjelasan mengenai tujuan kegiatan pembelajaran dari guru, kegiatan mengerjakan tugas dari guru masih ada siswa yang belum berpartisipasi aktif dengan kelompoknya dan tidak 
mendengarkan perintah yang diberikan oleh guru dengan baik. Kegiatan akhir pada pembelajaran siswa tidak membuat rangkuman hasil pembelajaran tentang pengurangan bilangan bulat. Kekurangan yang dimiliki pada siklus I pertemuan ke 1 akan dijadikan acuan untuk memperbaiki proses belajar siswa dan perlu adanya peningkatan pada pertemuan selanjutnya.Lembar observasi keterlibatan siswa pada siklus I pertemuan ke 2 ada juga beberapa tindakan yang belum dilaksanakan oleh siswa dan perlu adanya peningkatan untuk pertemuan di siklus selanjutnya. Hasil observasi yang terdapat pada lembar observasi kegiatan belajar siswa dalam kegiatan pembelajaran terdapat beberapa yang belum dilaksanakan siswa dengan baik, yang dilakukan pada pertemuan ke 2 sama halnya yang dilakukan pada pertemuan ke 1 yaitu siswa belum mendapatkan kejelasan tentang tujuan kegiatan pembelajaran yang akan dilaksanakan, untuk kegiatan menanggapi atau menyanggah permasalahan dari kelompok lain masih ada siswa yang belum berpartisipasi dengan baik dan aktif kepada kelompoknya. Kegiatan akhir pembelajaran siswa tidak membuat rangkuman hasil pembelajaran tentang materipengurangan bilangan bulat. Kekurangan pada siklus I pertemuan ke 2 akan dijadikan sebagai acuan untuk memperbaiki proses belajar siswa dan perlu ditingkatkan pada pertemuan selanjutnya.

Pertemuan kedua siklus II dilaksanakan pada tanggal 28 Maret 2017. Pada tahap awal guru mengkondisikan siswa, guru mengucapkan salam, berdo'a serta mengecek kehadiran siswa, apersepsi dengan mengulang materi sebelumnya dan menyampaikan indikator pencapaian kompetensikompetensi yang diharapkan. Pada tahap inti guru membahas hasil kerja kelompok yang telah dikerjakan pada pertemuan pembelajaran sebelumnya, guru memberi kesempatan kepada setiap siswa untuk bertanya hal-hal tentang materi yang telah dipelajari yang mungkin masih sulit dimengerti oleh siswa, kemudian guru memberikan kesempatan kepada siswa lain untuk memberi tanggapan atau sanggahan terhadap pertanyaan yang mungkin muncul saat pembelajaran. Pada tahap penutup guru meluruskan kesalahpahaman yang mungkin dialami siswa saat mengikuti kegiatan pembelajaran, kemudian guru menutup kegiatan pembelajaran dengan berdo'a dan mengucapkan salam. Setelah guru melaksanakan pembelajaran pada siklus II, yang menjadi refleksi pada siklus ini adalah meningkatnya aktivitas belajar. Guru telah menerapkan pendekatan pembelajaran Problem Based Learning (PBL) dengan sangat baik. Dilihat dari aktivitas siswa, siswa telah mengikuti pembelajaran dengan sangat baik dan tidak mengganggu kelompok lain. Siswa terlihat aktif dan antusias mengikuti pembelajaran karena memahami proses pendekatan pembelajaran Problem Based Learning (PBL). Selain itu, memberikan tanggapan, sanggahan serta guru meluruskan kesalah pahaman membuat siswa memahami semua topik yang dibahas.

Refleksi digunakan sebagai bahan untuk memantapkan apakah dalam kegiatan proses pembelajaran yang dilakukan pada siklus II sudah sesuai dengan indikator keberhasilan yang ingin dicapai oleh peneliti atau belum. Hasil analisis data yang diperoleh pada siklus II sebagai berikut, dari hasil observasi kegiatan mengajar guru yang dilaksanakan pada siklus 2 pertemuan ke 1 bahwa hampir semua kegiatan yang direncanakan telah dilakukan oleh guru dalam kegiatan pembelajaran pertemuan ke 1 pada siklus II. Kekurangan yang ada pada siklus I mengalami perbaikan yaitu ketika memulai pembelajaran guru sudah menyampaikan tujuan pembelajaran dan kegiatan yang dilakukan dalam proses pembelajaran.Berdasarkan hasil observasi kegiatan belajar mengajar/ keterlibatan siswa pada siklus II pertemuan ke 1 bahwa adanya kekurangan pada siklus I sudah mengalami perbaikan antara lain siswa sudah berani menanggapi ataupun menyanggah permasalahan dari kelompok lain atau dari guru, lebih aktif dalam berdiskusi dengan kelompoknya, pada saat kegiatan akhir siswa tidak membuat rangkuman hasil pembelajaran tentang materi benda dan sifat bahan pembentuknya yang sudah dijelaskan.

Setelah melakukan analisa terhadap 2 siklus yang dilaksanakan, maka dapat disimpulkan bahwa penggunaan model pembelajaran $P B L$ materi pengurangan bilangan bulat, dan operasi bilangan campuran menunjukkan peningkatan hasil aktivitas belajar Matematika. Tabel 1 presentase perbandingan aktivitas belajar Matematika dari siklus I dan siklus II. 
Peningkatan Aktivitas Belajar Matematika Melalui Pendektan Problem Based Learning Bagi Siswa Kelas 4 SD (Normala Rahmadani N., Indri Anugraheni)

Tabel.1

Perbandingan aktivitas belajar Matematika siklus I dan sikuls II kelas 4 SDN Pettirejo

\begin{tabular}{lccc}
\hline \multirow{2}{*}{ No. } & Indikator Aktivitas & \multicolumn{2}{c}{ Prsentase } \\
\cline { 3 - 4 } & & Siklus I & Siklus II \\
\hline 1. & Visual & $95,8 \%$ & $100 \%$ \\
\hline 2. & Lisan & $37,5 \%$ & $79,16 \%$ \\
\hline 3. & Mendengarkan & $62,5 \%$ & $70,83 \%$ \\
\hline 4. & Menulis & $79,1 \%$ & $83,33 \%$ \\
\hline 5. & Mental & $62,5 \%$ & $70,83 \%$ \\
\hline
\end{tabular}

Berdasarkan tabel 1, nampak bahwa perbandingan aktivitas belajar Matematika melalui pendekatan PBL siswa kelas 4 SDN Petirrejo Kecamatan Ngadirejo dari siklus I ke Siklus II mengalami peningkatan. Dari aktivitas visual dari siklus I presentasenya 95,8\% ke siklus II yaitu $100 \%$ meningkat prsentasenya dari siklus I ke siklus II sebesar 4,2\%. Pada aktivitas lisan dari siklus I presentasenya 37,5\% ke siklus II 79,16\% meningkat prsentasenya dari siklus I ke siklus II sebesar 41,6\%. Pada aktivitas mendengarkan dari siklus I presentasenya 62,5\% ke siklus II 70,83\% meningkat prsentasenya dari siklus I ke siklus II sebesar 8,33\%. Pada aktivitas menulis dari siklus I 79,1\% ke siklus II presentasenya $83,33 \%$ mengalami peningkatan sebesar $12,5 \%$, dan pada aktivitas mental presentase siklus I dari 62,5 ke siklus II 70,83\% mengalami peningkatan sebesar 8,33\%.

\section{Pembahasan}

Dari data perbandingan aktivitas belajar Matematika menunjukkan peningkatan presentase aktivitas belajar Matematika melalui pendekatan Problem Based Learning dari siklus I ke siklus II. Terbukti dari hasil observasi siswa kelas 4 SDN Petirrejo Kecamatan Ngadirejo Kecamatan Ngadirejo aktivitas belajar Matematika siklus I, nampak bahwa pada aktivitas visual diperoleh presentase berjumlah 95,8\%, pada aktivitas lisan diperoleh presentase 37,5\%, pada aktivitas mendengarkan diperoleh presentase $62,5 \%$, pada aktivitas menulis diperoleh presentase $79,1 \%$, dan pada aktivitas mental diperoleh 62,5\%. Kemudian siklus II diperoleh hasil aktivitas belajar Matematika nampak bahwa pada aktivitas visual diperoleh presentase $100 \%$, pada aktivitas lisan terdapat $79,16 \%$, pada aktivitas mendengarkan diperoleh 70,83\%, pada aktivitas menulis diperoleh 83,33\%, dan pada aktivitas mental diperoleh presentase $70,83 \%$.

Temuan ini bermakna siswa mampu melakukan aktivitas belajar Matematika melalui pendekatan Problem Based Learningyaitu orientasi siswa pada masalah yaitu aktivitas siswa mendengarkan, mengorganisasi siswa untuk belajar aktivitas lisan siswa, membimbing pengalaman individu atau kelompok aktivitas visual siswa, mengembangkan dan menyajikan hasil karya aktivitas siswa menulis, analisis dan evaluasi proses pemecahan masalah aktivitas mental siswa. Temuan ini sejalan dengan penelitian Hosnan (2014) dan Sudirman (2014).

Perbandingan presentase dari siklus I dan siklus II nampak pada aktivitas belajar Matematika melalui pendekatan Problem Based Learning siswa kelas 4 SDN Petirrejo Kecamatan Ngadirejo dari siklus I ke Siklus II mengalami peningkatan. Dari aktivitas visual dari siklus I presentasenya 95,8\% ke siklus II yaitu $100 \%$ meningkat prsentasenya dari siklus I ke siklus II sebesar 4,2\%. Pada aktivitas lisan dari siklus I presentasenya 37,5\% ke siklus II 79,16\% meningkat prsentasenya dari siklus I ke siklus II sebesar $41,6 \%$. Pada aktivitas mendengarkan dari siklus I presentasenya $62,5 \%$ ke siklus II $70,83 \%$ meningkat prsentasenya dari siklus I ke siklus II sebesar 8,33\%. Pada aktivitas menulis dari siklus I 79,1\% ke siklus II presentasenya $83,33 \%$ mengalami peningkatan sebesar $12,5 \%$, dan pada aktivitas mental presentase siklus I dari 62,5 ke siklus II 70,83\% mengalami peningkatan sebesar $8,33 \%$. Berdasarkan uraian tentang data hasil penelitian, dapat disimpulkan bahwa adanya peningkatan aktivitas belajar Matematika melalui pendekatan Problem Based Learningsiswa kelas 4.

Keampuhan model $P B L$ mampu meningkatkan aktivitas belajar siswa. Keampuhan ini terbuktipada aktivitas mendengarkan ini akan nampak setelah guru menjelaskan materi pembelajaran dan siswa mendengrakan. Pada tahap mengidentifikasi permasalahan akan diukur berdasarkan 
indikator aktivitas menulis, aktivitas mengidentifikasi permasalahan akan dilakukan secara tertulis. Pada tahap merumuskan masalah termasuk dalam indikator aktivitas lisan, aktivitas merumuskan masalah akan nampak setelah siswa selesai melakukan masalah. Masalah yang telah dirumuskan siswa, dicari solusi penyelesaiannya melalui aktivitas menyimak handout. Aktivitas menyimak handout termasuk dalam indikator aktivitas visual. Siswa diberi tugas untuk mencari informasi tentang topik permasalahan. Informasi yang diperoleh siswa dianalisis guna penyusunan laporan solusi permasalahan. Pada aktivitas ini sudah nampak aktivitas pemecahan masalah. Aktivitas menganalisis informasi termasuk dalam indikator aktivitas mental. Siswa menyusun laporan hasil analisis informasi, aktivitas menyusun laporan termasuk dalam indikator aktivitas menulis. Laporan yang telah disusun oleh siswa dipresent asikan di depan kelas secara berkelompok. Kelompok lain yang mendengarkan memberikan tanggapan atau pendapatnya atas laporan yang disampaikan kelompok lain. Aktivitas mempresentasikan termasuk dalam indikator aktivitas lisan. Siswa bersama guru merefleksi kegiatan $P B L$, guru bertanya seputar kegiatan pembelajaran yang telah siswa alami. Aktivitas refleksi termasuk dalam indikator aktivitas lisan, aktivitas ini akan nampak pada saat siswa bertanya jawab secara lisan seputar kegiatan pembelajaran yang telah siswa alami.Temuan ini sejalan dengan penelitian Hosnan (2014) dan Sudirman (2014) dan juga hasil penelitian Sri Giarti (2014) yang menunjukkan bahwa model PBL terintegrasi penilaian autentik dapat meningkakan keterampilan proses pemecahan masalah matematika siswa kelas VI SD Negeri 2 Bengle, Wonosegoro - Boyolali.

\section{SIMPULAN DAN SARAN \\ Simpulan}

Berdasarkan pembahasan dan hasil penelitian, yang telah dilakukan pada siklus I dan siklus II yang telah dijabarkan pada Bab IV dapat disimpulkan bahwa peningkatan aktivitas belajar Matematika dapat diupayakan melalui Pendekatan Problem Based Learning siswa kelas 4 SDN Petirrejo Kecamatan Ngadirejo semester 2 tahun 2017 terbukti mengingkat dengan berdasarkan urian data presentase aktivitas belajar dari siklus I dan siklus II nampak pada aktivitas belajar Matematika melalui pendekatan Problem Based Learningsiswa kelas 4 SDN Petirrejo Kecamatan Ngadirejo dari siklus I ke siklus II. Dari aktivitas visual dari siklus I presentasenya 95,8\%, siklus II diperoleh presentase $100 \%$ meningkat prsentasenya dari siklus I ke siklus II sebesar $4,2 \%$. Pada aktivitas lisan dari siklus I presentasenya 37,5\%, siklus II diperoleh presentase $79,16 \%$ meningkat prsentasenya dari siklus I ke siklus II sebesar 41,6\%. Pada aktivitas mendengarkan dari siklus I presentasenya $62,5 \%$, siklus II diperoleh presentase 70,83\% meningkat prsentasenya dari siklus I ke siklus II sebesar 8,33\%. Pada aktivitas menulis dari siklus I 79,1\%, siklus II diperoleh presentase 83,33\% mengalami peningkatan sebesar $12,5 \%$, dan pada aktivitas mental presentase siklus I dari $62,5 \%$, siklus II diperoleh presentase 70,83\% mengalami peningkatan sebesar 8,33\%.

Penelitian ini dinyatakan berhasil ditunjukkan oleh mengikatnya presentase setiap aktivitas dari siklus I ke siklus II. Peningkatan yang terjadi adanya pendekatan Problem Based Learning siswa terlibat langsung dalam menyelesaikan suatu permasalahan yang diberikan oleh guru dan guru bertindak sebagai fasilitator.

\section{Saran}

Berdasarkan hasil penelitian tindakan kelas pada kelas 4 SDN Petirrejo Kecamatan Ngadirejo, maka saran yang diberikan yaitu, peneliti menyarankan kepada siswa untuk lebih aktif dan dapat bekerjasama antar siswa satu dengan lainnya dalam kegiatan pembelajaran secara kelompok, dengan penggunaan model pembelajaran Problem Based Learning siswa harus meningkatkan kemampuan penyelesaian masalah nyata dengan pengalaman dalam kehidupan sehari-hari, guru hendaknya mendesain pembelajaran dengan menggunakan pendekatan Problem Based Learning untuk meningkatkan aktivitas belajar siswa. Melalui pembelajaran menggunakan pendekatan Problem Based Learning guru dapat meningkatkan keterampilan dalam mengajar serta aktivitas siswa dalam pembelajaran, kepala sekolah hendaknya menghimbau kepada guru untuk menggunakan pendekatan Problem Based Learning dalam melaksanakan pembelajaran, sehingga dapat tercipta suasana belajar yang menarik serta meningkatkan aktivitas siswa serta berpartisipasi dalam memantau kegiatan pembelajaran yang berlangsung di kelas. 
Peningkatan Aktivitas Belajar Matematika Melalui Pendektan Problem Based Learning Bagi Siswa Kelas 4 SD (Normala Rahmadani N., Indri Anugraheni)

\section{DAFTAR PUSTAKA}

Agustin, Vivin Nurul. 2013. Peningkatan Aktivitas dan Hasil Belajar Siswa Melalui Model Problem Based Learning (PBL). Journal of Elementary Education. 2 (1), 36-44.

Arends, Richard I. 2008. Learning To Teach. Yogyakarta: Pustaka Belajar.

Hamalik, Oemar. 2014. Proses Belajar Mengajar. Jakarta: PT Bumi Aksara.

Heruman. 2013. Model PembelajaranMatematika Di SekolahDasar. Bandung:PT Remaja Rodaskarya.

Hosnan, M. 2014. Pendekatan Saitifik dan Kontekstual. Jakarta:Ghalia Indonesia.

Indri, Anugraheni. 2017. Penggunaan Portofolio dalam Perkuliahan Pembelajaran. Jurnal Pendidikan Dasar Perkhasa. http://jurnal.stkippersada.ac.id/ index.php/Perkhasa/ article/view/211

Ismunamto, dkk. 2011. EnsiklopediaMatematika 1. Jakarta: IkrarMandiriabadi.

Rohani, Ahmad. 2010. PengelolaanPengajaran. Jakarta: RinekaCipta.

Riyanto, yatim. 2010. Paradigma baru pembelajaran. Jakarta: Kencana Prenada Media Group.

Rusman. 2013. Model-Model Pembelajaran. Jakarta: PT Rajagrafindo persada.

Susanto, Ahmad. 2013. TeoriBelajar Dan Pembelajaran Di SekolahDasar.Jakarta: Kencana.

Usman, Uzer. 2011. Menjadi Guru Profesional. Bandung: PT Remaja Rosdakarya.

Undang Undang Republik Indonesia Nomor 20 Tahun 2003 tentang Sistem Pendidikan Nasional. 2003. Jakarta: Depdikbud.

Sardiman. 2014. Interaksi dan Motivasi Belajar Mengajar. Depok: PT Rajagrafindo Persada.

Sari, Deni Kartika. 2013. Penerapan Model Problem Based Learning dengan Media Power Point untuk Meningkatkan Aktivitas Belajar IPA Siswa Kelas 5 SDN 2 Mudal. Skripsi. Semarang: Universitas Negeri Semarang.

Sri Giarti. 2014. Peningkatan Keterampilan Proses Pemecahan Masalah dan Hasil Belajar Matematika Menggunakan Model $P B L$ Terintegrasi Penilaian Autentik Pada Siswa Kelas VI SDN 2 Bengle, Wonosegoro. Scholaria, Vol. 4, No. 3, September 2014: 1 3-27

Sugiyono. 2012. Metode Penelitian Kuatitatif, Kualitatif dan Kombinasi (Mixed Metods). Bandung:

Alfabeta.Wardani Naniek Sulistya, Slameto dan Adi Winanto. 2012. Asesmen Pembelajaran SD. Salatiga:Widya Sari Press.

Wardani Naniek Sulistya dan Slameto. 2012. Evaluasi Proses dan Hasil Belajar. Salatiga: Widya Sari Press.

Warsono, Hariyanto. 2013. PembelajaranAktif. Bandung: PT. RemajaRosdaskarya.

\section{PROFIL SINGKAT}

Penulis 1

Saya bernama Normala Rahmadani Nugroho. Saya lahir di Temanggung, 13 Februari 1995, sekarang saya berusia 22 tahun. Saya lulus SMA N 1 Candiroto jurusan IPS tahun 2013, kemudian saya melanjutkan ke jenjang perguruan tinggi di Universitas Kristen Satya Wacana (UKSW) Salatiga jurusan Pendidikan S1 Program Studi Pendidikan Guru Sekolah Dasar (PGSD).

Penulis 2

Indri Anugraheni, S.Pd, M.Pd. Lulus S1 tahun 2006, Prodi Pendidikan Matematika Universitas Sanata Dharma. Lulus S2 tahun 2010, Program Studi Pendidikan Dasar Universitas Negeri Yogyakarta. Saat ini menjadi Dosen di Program Studi Pendidikan Guru Sekolah Dasar (PGSD) UKSW. 